\title{
EXPERIMENTAL EVALUATION OF THE ROLE OF SYMBIOTIC AND APOSYMBIOTIC, CULEX PIPIENS MOSQUITOES IN THE TRANSMISSION OF HEPATITIS C VIRUS (HCV)
}

\section{By}

MOSTAFA I. HASSAN ${ }^{1}$, ALY F. MOHAMMED ${ }^{2}$, KOTB M. HAMMAD', A. GABARTY ${ }^{3}$, AND THARWAT A. SELIM ${ }^{1}$

Department of Zoology ${ }^{1}$, Faculty of Science, Al-Azhar University, Nasr City, Cairo, and VACSERA ${ }^{2}$, Giza, and Department of Natural Products ${ }^{3}$, National Center for

Radiation Research and Technology, Atomic Energy Authority, Cairo, Egypt.

$\left({ }^{\star}\right.$ Correspondence: E-mail:mostafa012@gmail.com)

\section{Abstract}

The present study evaluated the potential role of Culex pipiens mosquitoes in the transmission of HCV, post being fed on an infected blood with a viral load of $1.3 \times 10^{6} \mathrm{IU} / \mathrm{ml}$.in symbiotic mosquitoes and $1.2 \times 10^{6} \mathrm{IU} / \mathrm{ml}$.in aposymbiotic one. Mouth parts, mid-gut and salivary glands in both symbiotic and aposymbiotic mosquitoes at different time intervals were tested for evaluation of viral load using real-time PCR for up to 60min and up to 5, 13 day in case of mouth parts, mid-gut and salivary glands respectively. It was observed that the viral load was decreased by increasing the time post feeding in mid-gut and mouth parts in both symbiotic and aposymbiotic mosquitoes so, there is a negative relationship between the HCV load and feeding time. On the other hand, HCV was not detected in salivary glands in both symbiotic and aposymbiotic mosquitoes during the period of detection. The results showed that the mechanical transmission through mouth parts in both symbiotic and aposymbiotic mosquitoes are plausible, while biological transmission through symbiotic and aposymbiotic mosquitoes did not occur.

Key words: Culex pipiens, Symbiotic, Aposymbiotic, HCV, Transmission.

\section{Introduction}

The mosquitoes are vectors of many vertebrate blood parasites. In Egypt Culex pipens has a wide distribution and is the main vector of Rift Valley Fever (RVF) virus (Megan et al, 1980; Darwish and Hoogastraal, 1981; El Bahnasawy et al, 2013a), Wuchereria bancrofti (Khalil et al, 1930; Gad et al, 1996; Abdel-Hamid et al, 2013) and Western Nile Virus (Pelah et al, 2002; El Bahnasawy et al, 2013b). Hassan et al. (2003); Pybus et al. (2007); Tarish et al. (2014) and El Kholy et al. (2017) studied the possibility of the HCV experimental transmission by different mosquitoes.

Hepatitis C Virus infection is one of the major public health problems in both developed and developing countries since discovering at 1989 (Choo et al, 1989; Alter et al, 1989). It was estimated that $\mathrm{HCV}$ infect 200 million peoples $(3 \%)$ of the world's population and there are at least 21.3 million HCV carriers in the Eastern Mediterranean countries (Sy and Jamal,
2006). The infection acquired mainly via parenteral route (Karaca et al, 2006), and also perinatally (Indolfi and Resti, 2009), but there is $(30-40 \%)$ of infected cases were without identifiable route (Hayashi and Furusyo, 2010).

Many investigators suggested that the mechanical transmission of HCV by mosquitoes was plausible (Germi et al, 2001; Hassan et al, 2003; Pybus et al, 2007). This was in accordance to Kamal (2008) who reported that one viral particle was perhaps sufficient to induce infection via parenteral route. El Kholy et al. (2017) reported that the mosquito $C x$. pipiens may be a potential vector of HCV. However, the biological and mechanical of $\mathrm{HCV}$ transmission by mosquitoes showed negative results. Low HCV RNA titers in patient sera and different species tropisms for $\mathrm{HCV} / \mathrm{RNA}$ replication are probably the reasons why the mechanical and biological HCV transmission did not occur in mosquitoes (Chang et al, 2001). 
Bacteria exist naturally in the mid-gut of wild and laboratory-reared mosquitoes (Chao and Wistreich, 1960; 1995; Demaio et al, 1996; Pumpuni et al, 1996) and sand flies (Schlein et al, 1985; Hassan et al, 1998). Bacteria occurring in gut of haematophagous insects may have an important role in epidemiology of human infectious diseases. Such bacteria may interfere with the development of medically important pathogens. The high midgut counts of Gram-negative bacteria significantly reduced oocysts in infected Anopheles (Seitz et al, 1987; Beier et al, 1994; Pumpuni et al, 1996).

The present study aimed to evaluate the role of symbiotic and aposymbiotic Culex pipiens mosquitoes in the transmission of Hepatitis C virus (HCV) even biologically or mechanically.

\section{Materials and Methods}

Mosquitoes rearing technique: Mosquito used was Culex pipiens L., obtained from the Medical Entomology Institute Dokki, Giza. Culex was reared for several generations, in the Insectary of Medical Entomology at the Department of Zoology, Faculty of Science, under controlled laboratory conditions at temperature of $27 \pm 2^{\circ} \mathrm{C}$, relative humidity $70 \pm 10 \%$ and $12-12$ light-dark regime.

Elimination of bacteria: In order to eliminate mi d-gut bacteria, $C$. pipiens females were fed on sponge piece soaked in a feeding medium, which composed of $10 \mathrm{gm}$. sucrose and $0.014 \mathrm{~g}$ of a wide spectrum antibiotic (Tarivid) dissolved in $100 \mathrm{ml}$. distilled water. The mixture was kept in a refrigerator at $4^{\circ} \mathrm{C}$. A sterile sponge piece was saturated with the mixture and offered daily to $C$. pipiens females. This process was continued for a period of 3 days after adult emergence. This group of insects was used for aposymbiotic test (Fouda et al, 2013).

Experimental infection of with HCV: All experiments were carried out at Genetic Engineering Center, Faculty of Science, AlAzhar University under controlled laboratory conditions.
Feeder membrane preparation: The feeder membrane (Fig. 1) consisted of two tubes, first one for positive blood meal surrounded with the second one for the current water which connected with water bath at $37^{\circ} \mathrm{C}$ to keep the blood temperature. The $1^{\text {st }}$ tube with two ends, the bottom, covered with chicken membrane and the upper covered with a piece of cotton after a blood meal entered. The $2^{\text {nd }}$ tube with two ends also, for income and outcome the current water.

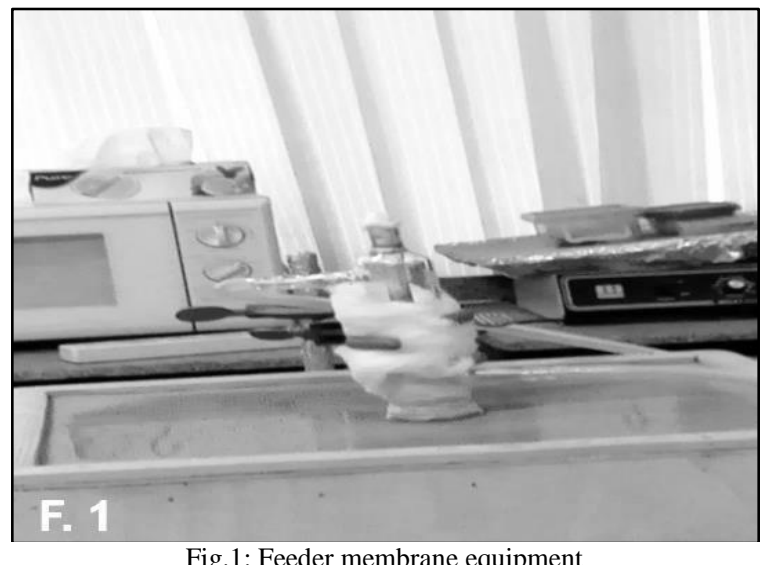

Blood preparation: Two blood bags were brought from Blood Bank at VACCERA, Dokki, Giza-Egypt, post signing approval of blood bank QC Department. Blood bags were tested for positive reactivity to $\mathrm{HCV}$ virus titer using PCR to estimate the viral load. Preparing and dissecting samples: Mosquitoes were kept in feeding cages and they were provided daily with $10 \%$ sucrose solution for a period of one day after emergence. The sugar solution was removed $24 \mathrm{~h}$ before the blood meal to increase bloodfeeding. After that; the females were allowed to take a positive blood meal via the feeder membrane, then the specimens were dissected and prepared (Fouda et al, 2013).

Viral load in different parts of dissecting mosquitoes: Culex pipiens were collected for viral load detection in mouth parts, at once, $30 \mathrm{~min}$, and 60min, mid-gut at once, after 12 $\mathrm{hr}, 1^{\text {st }}, 2^{\text {nd }}, 3^{\text {rd }}, 4^{\text {th }} \& 5^{\text {th }}$ days and in salivary glands at $5,6,11,12, \& 13$ days after feeding on HCV infected blood respectively. Killed mosquito mouth parts, mid gut and 
salivary glands were placed in a little amount of normal saline solution under freezing conditions to be examined using real-time PCR.

\section{Results}

Evaluation of infectivity titer in mouth parts of test mosquitoes: There was a decrease in $\mathrm{HCV}$ titer percentage induced by increasing post feeding time in both symbiotic and aposymbiotic $C$. pipiens mouth parts. There was a negative correlation between HCV titer and time post feeding (Tab. 1, Fig. 2). There was a depletion of viral load in infected blood fed aposymbiotic $C$. pipiens than in symbiotic ones at zero time. biotic $C$. pipiens 30min. post feeding and opposite was clear one hr post feeding in symbiotic ones. The mechanical transmission through mouthparts of symbiotic and aposymbiotic $C$. pipiens might be plausible.

There was a decrease in HCV titer by increasing time, with a negative correlation between HCV titer and time (Tab, 2; Fig. 3) but, an increase in viral load in mid gut of aposymbiotic $C$. pipiens than symbiotic one related to time/day. Also, no $\mathrm{HCV}$ titer at 5, $6,11,12$ \& 13 days post feeding, without correlation between time and titer. So, no biological transmission occurred via symbiotic and aposymbiotic $C$. pipiens.

There was an elevate viral load in aposym-

Table 1: HCV titer at mouth parts in symbiotic and aposymbiotic mosquitoes relative to time post feeding.

\begin{tabular}{|c|c|c|c|c|c|}
\hline $\begin{array}{l}\text { Post-feeding } \\
\text { (min) }\end{array}$ & $\begin{array}{c}\text { Tested } \\
\text { mosquitoes }\end{array}$ & $\begin{array}{c}\text { Symbiotic HCV titer } \\
\text { IU/ML\% /10 females }\end{array}$ & $\begin{array}{c}\text { Symbiotic HCV } \\
\text { titer/ female } \%\end{array}$ & $\begin{array}{c}\text { Aposymbiotic HCV titer } \\
\text { IU/ML\% /10 females }\end{array}$ & $\begin{array}{c}\text { Aposymbiotic HCV } \\
\text { titer / female } \%\end{array}$ \\
\hline 0 & 10 & 116122 & 11612.2 & 100129 & 10012.9 \\
\hline 30 & 10 & 36046 & 3604.6 & 46548 & 4654.8 \\
\hline 60 & 10 & 1381 & 138.1 & & - \\
\hline
\end{tabular}

Tab le 2: HCV titer in the mid-gut of symbiotic and aposymbiotic mosquitoes relative to time post feeding.

\begin{tabular}{|l|l|l|l|l|l|}
\hline $\begin{array}{l}\text { Post-feeding } \\
\text { (days) }\end{array}$ & $\begin{array}{l}\text { Tested } \\
\text { mosquitoes }\end{array}$ & $\begin{array}{l}\text { Symbiotic HCV titer } \\
\text { IU/ML\%./10 females }\end{array}$ & $\begin{array}{l}\text { Symbiotic HCV } \\
\text { titer/female \% }\end{array}$ & $\begin{array}{l}\text { Aposymbiotic HCV titer } \\
\text { IU/ML\%/ 10 females }\end{array}$ & $\begin{array}{l}\text { Aposymbiotic HCV } \\
\text { titer/female \% }\end{array}$ \\
\hline 0 & 10 & 244336 & 24433.6 & 299576 & 29957.6 \\
\hline 0.5 & 10 & 141051 & 14105.1 & 210993 & 21099.3 \\
\hline 1 & 10 & 129093 & 12909.3 & 160737 & 16073.7 \\
\hline 2 & 10 & 98302 & 9830.2 & 148019 & 14801.9 \\
\hline 3 & 10 & 12348 & 1234.8 & 106889 & 10688.9 \\
\hline 4 & 10 & 1641 & 164.1 & 85790 & 8579 \\
\hline 5 & 10 & 1073 & 107.3 & 74789 & 7478.9 \\
\hline
\end{tabular}

Table 3: HCV titer in the salivary glands of symbiotic and aposymbiotic mosquitoes relative to time post feeding.

\begin{tabular}{|c|c|c|c|c|c|}
\hline $\begin{array}{c}\text { Post-feeding } \\
\text { (days) }\end{array}$ & $\begin{array}{c}\text { Tested } \\
\text { C. pipiens }\end{array}$ & $\begin{array}{c}\text { Symbiotic HCV titer } \\
\text { IU/ML\%/ 10 females }\end{array}$ & $\begin{array}{c}\text { Symbiotic HCV } \\
\text { titer \% / female }\end{array}$ & $\begin{array}{c}\text { Aposymbiotic HCV titer } \\
\text { IU/ML\% per 10 females }\end{array}$ & $\begin{array}{c}\text { Aposymbiotic HCV } \\
\text { titer \%/ female }\end{array}$ \\
\hline 5 & 10 & - & - & - & - \\
\hline 6 & 10 & - & - & - & - \\
\hline 11 & 10 & - & - & - & - \\
\hline 12 & 10 & - & - & - & - \\
\hline 13 & 10 & - & - & - & - \\
\hline
\end{tabular}

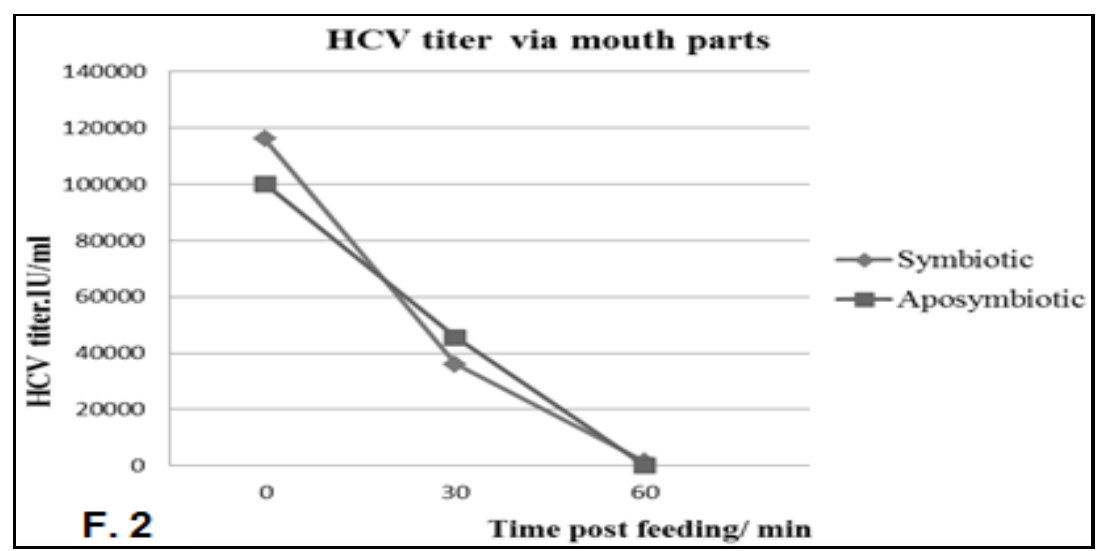

Fig. 2: HCV genome of mouth parts from symbiotic and aposymbiotic C. pipiens fed on infected blood at different intervals post feeding. 


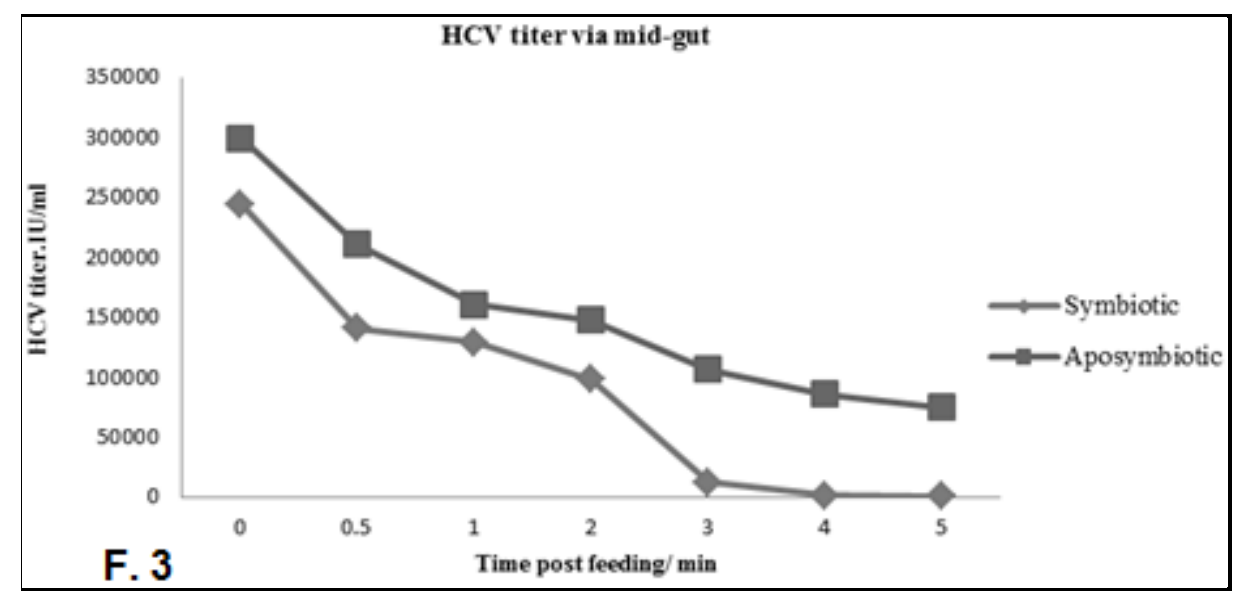

Fig. 3: $\mathrm{HCV}$ genome in mid-gut of symbiotic and aposymbiotic C. pipiens fed on infected blood at different intervals post feeding.

\section{Discussion}

The current study investigated feeding $C$. pipiens on infected blood via feeder membrane with HCV genotype IV of a known viral concentration of $\left(1.3 \times 10^{6} \mathrm{IU} / \mathrm{ml}\right)$ in blood meal of symbiotic mosquitoes and with viral concentration of $\left(1.2 \times 10^{6} \mathrm{IU} / \mathrm{ml}\right)$ in blood meal of aposymbiotic one. The results showed that all mosquitos' moth parts examined at time zero, $30 \mathrm{~min}$ and $60 \mathrm{~min}$ post-feeding were positive for $\mathrm{HCV}$ genome using real time-PCR analysis. These results were in harmony with Hassan et al. (2003) and Tarish et al. (2014) despite of presence of some variations in the period length at which the virus was recovered from mosquitoes after feeding on infected blood. Hassan et al. (2003) reported that HCV-RNA was detected in heads of symbiotic females at $3 \mathrm{hr}$ post feeding and in aposymbiotic ones the virus was detected afterwards in head and guts. The procedure implemented can be described as the variation in the longer persistence of $\mathrm{HCV}$ shown $(3 \mathrm{~h}$ ) in comparison to that reported in the present study $(1 \mathrm{~h})$ may be attributed to many factors including the viral genotype, temperature and the environmental factors affected insect breeding but not limited to the virus titer.

Also, Tarish et al. (2014) investigated the infectivity through mouthparts of female $\mathrm{Cu}$ lex spp. mosquitoes, previously fed on $\mathrm{HCV}$ infected blood, after maintaining their feed via Parafilm on non-infected blood placed in Petri dishes. In those studies no HCV ge- nomic RNA was detectable when using conventional RT-PCR analysis on samples collected from Petri dishes at 2 to 8 days port-feeding.

For the mechanical transmission to occur from an infective insect vector to a human host, infectious viral units on the mouth parts must come in contact with the healthy susceptible person through direct percutaneous exposure at the moment of insect probes the human skin. Such an event might occur when mosquito is disturbed while feeding on a person, when it flies to another person for feeding i.e. interrupted feeding (Sliver $e t a l$, 1996). Transfer equine infectious anemia virus from one horse to another by biting flies is a well-established mode of such mechanical transmission (Foil and Issel, 1991). Whether $\mathrm{HCV}$ can be transferred from an infected person to healthy one by this route of infection is still unknown.

However the present results showed a negative correlation between the HCV titer and time in symbiotic and aposymbiotic mosquitoes. Although the titer decreased when the time increased, it may contribute and raise probability of mechanical transmission of HCV. Thus, explained percent (30-40\%) of infected cases are without identifiable route (Hayashi and Furusyo, 2010). This agreed with Kamal (2008) who reported that one viral particle perhaps sufficient to induce infection through parenteral route.

Insects can transmit some pathogens incidentally, for instance, myxoma virus of rab- 
bit which is not an arbovirus, can be transmitted mechanically by mosquito after its mouth parts become contaminated after being fed on the infected rabbit with skin lesions (Strauss and Strauss, 2002). Transmission of HCV from person to person via contaminated proboscises was plausible (Tarish et al, 2014). Feeding of mosquitoes is a complex process at which fluid exchange occurs between the insect and its host. The insect inserts her saliva inside the host prior to and during blood feeding. Such process may present a good chance to virus transmission. Furthermore, the skin of an individual may become contaminated with $\mathrm{HCV}$ when certain individual kill or destroy the mosquito that harbor the virus, thus the contaminated hands act as a source of viral transmission through skin cuts. This may explain the high percentage of asymptomatic HCV infections among population without history of parenteral exposure to contaminated blood and/or other sources of the viral transmission (Hubalek, 2008).

In the present study, all the experiments showed a decrease in the virus titer by the time, with variation in the titer levels in aposymbiotic compared to symbiotic ones due to absence of mid-gut bacteria. The results agreed with Seitz et al. (1987); Beier et al. (1994) and Pumpuni et al. (1996) who reported that bacteria occurring in the gut of haematophagous insects may have an important role in epidemiology of human infectious diseases. Such bacteria may interfere with the development of medically important pathogens.

The prevalence of biologically transmitted pathogens in vectors can be low even though the pathogen might live in the vector for many days (Anderson and May, 1991). The low transmission coefficients that Pybus et al. (2007) reported the rapid decay of HCVvirus within a mechanical vector, suggested that prevalence of $\mathrm{HCV}$ infection amongst vectors was exceedingly low.

The present results agreed with Chang et al. (2001) who showed that the biological
$\mathrm{HCV}$ transmission by $C$. quinquefasciatus did not occur. Low HCV/RNA titers in patient sera and different species tropisms for HCV RNA replication are probably the reasons why biological HCV transmission did not occur in $C$. quinquefasciatus.

In the present study, all results showed negative HCV/RNA. These results agreed with Chang et al. (2001) who infected $C$. quinquefasciatus by intrathoracic inoculation using pulled disposable pipette needles to avoid possible mid-gut $\mathrm{HCV}$ barriers and even though the biological HCV transmission by $C$. quinquefasciatus was negative. The results showed that $C$. pipiens failed to be HCV biological transmitter.

Hassan et al, (2003) C. pipiens trapped from of HCV patients' homes or among the same organs of symbiotic (normal gut bacteria) and aposymbiotic (without gut bacteria) mosquitoes fed HCV positive blood by an artificial membrane feeder. They found by PCR, HCV/RNA only in heads of symbiotic mosquitoes collected from homes of HCV positive patients at $3 \mathrm{hr}$ and $6 \mathrm{hr}$ post-feeding. Virus was detected at $3^{\text {rd }} \& 8^{\text {th }}$ days post-fed in guts of the same group. They raised the possibility of the mechanical and/or biological transmission of $\mathrm{HCV}$ by $C$. pipiens, and pave the way to study the effect of gut bacteria in a trial to identify an anti-HCV agent. Also, El Kholy et al. (2017) reported that $\mathrm{HCV}$ positive strands were detected in salivary glands of mosquito adults at a week post-feeding

For the biological transmission to occur from an infective insect vector to man, the virus must be replicated such as mosquitoand tick-borne flaviviruses are zoonotic transmitted through haematophagous insects during blood meal feeding. Viruses obtained from vertebrate host initially replicated in the mid-gut within 5-7 minutes of exposure and then virus spreads to other tissues via haemolymph and transmitted with saliva during blood meal (Blair et al, 2000). The period from the initial infection in the midgut to when the vector transmits the virus is 
termed the extrinsic incubation period (EIP), and this time period varies from7 to 14 days (Ramirez and Dimopoulos 2008). However, viruses were detected in the salivary glands of DENV-infected Aedes aegypti as early as 24hrs (Luplertlop et al, 2011), Urban Chikungunya (Humphrey et al, 2017), Yellow Fever virus (Klitting et al, 2018), as well as $\mathrm{Zi}$ ka virus (Tham et al, 2018). Consequently, the EIP depended on the virus, the mosquito and certain environmental factors (Ramirez and Dimopoulos, 2010).

Generally speaking, the major role in the transmission of HBV and/or HCV infection was played by the virus concentration on the infecting materials, high in blood and blood products, much lower in ascites and in cerebrospinal fluid and at non-infectious concentrations in feces, urine, sweat, vomit and tears (Coppola et al, 2016). Undoubtedly, the HBV and HCV are blood-borne infections, with significant transmission occurring through unsafe injections and medical procedures, and less commonly by sexual contact (Demsiss et al, 2018).

The health-care workers worldwide are, thus, at greater risk of acquiring these two blood-borne infections from percutaneous (needle-stick/sharp instrument) injuries or other types of occupational exposures, and the incidence of this infection among them has been estimated to be four times the level in the general population (Ciorlia and Zanetta, 2005). Needle-stick accidents with percutaneous inoculation is a well-documented $\mathrm{HBV}$ and HCV transmission, with seroconversion rate of $10-30 \%$ following needle stick exposure to HBV infected blood and about 2.0\% for HCV (Tarantola et al, 2005). Even in malaria which used the female Anopheles-vector for cyclopropagative biological transmission, was proved to be occupational needle-stick injury (Abdel-Motagaly et al, 2017). Overall the number of the health-care workers annually exposed to the different sharp injuries contaminated with HBV and HCV was estimated to reach 2.1 million and 926,000, respectively (Prüss-
Ustün et al, 2005). The protection of health care workers via immunization (for HBV), use of protective equipment and post-exposure management was therefore very critical to prevent occupational risk of exposure to the transmission of these blood-borne viruses (Deuffic-Burban et al, 2011).

Egypt was experiencing an HCC epidemic largely due to widespread HCV infection (Eldin et al, 2014), with the world's highest infection prevalence $(\sim 10 \%)$ in 2008 , and a 2015 HCV seroprevalence of 6.3\% (Egypt Health Issues Survey, 2015). HCV transmission was still ongoing in Egypt, with new cases estimated at 2.4/1000 person-years (El-Akel et al, 2017). Nowadays, the use of sofosbuvir-related therapies producing improved treatment success had permitted an updated, nationwide, HCV treatment programme with the expanded coverage ( $\mathrm{Ma}$ et al, 2018).

\section{Conclusion}

The outcome results showed that the mechanical transmission via mouth-parts of the symbiotic and/or aposymbiotic female Culex pipiens might be plausible. Biological transmission via salivary glands of $C$. pipiens symbiotic and aposymbiotic did not occur.

Nevertheless, the accidental needle-stick injuries must be in mind of all the healthcare workers.

\section{References}

Abdel-Hamid, YM, Soliman, MI, Kenawy, M A, 2013: Population ecology of mosquitoes and the status of bancroftian filariasis in El Dakahlia Governorate, the Nile Delta, Egypt. J. Egypt. Soc. Parasitol. 43, 1:103-13.

Abdel-Motagaly, AME, Ibrahim, AMA, Morsy, TA, 2017: An intervention program on blood protozoa acquired by needle stick injury and infection control. J. Egypt. Soc. Parasitol. 47, 2: 309-22.

Alter, HJ, Purcell, RH, Shih, JW, 1989: Detection of antibody to hepatitis $\mathrm{C}$ virus in prospectively followed transfusion recipients with acute and chronic non-A, non-B hepatitis Nat. Engl. J. Med. 321, 1:494- 500.

Anderson, RM, May, RM, 1991: Infectious Diseases of Humans, Dynamics and Control.Ox- 
ford University Press, New York.

Beier, MS, Pumpuni, CB, Beier, JC, Davis, JR, 1994: Effect of paraaminobenzoic acid geutamicinan on Plasmodium falciparum development in anophiline mosquitoes (Diptera: Culicidae). J. Med. Entomol. 31:561-5.

Blair, CD, Adelman, ZN, Olson, KE, 2000: Molecular strategies for interrupting arthropodborne virus transmission by mosquitoes. Clin. Microbiol. Rev. 13, 4:651-61.

Chang, TT, Tsuey, YC, Cheng, CC, Kung, C Y, Jun, NR, et al, 2001: Existence of Hepatitis $\mathrm{C}$ Virus in Culex quinquefasciatus after ingestion of infected blood: Experimental approach to evaluating transmission by mosquitoes. J. Clin. Microbiol. 39, 9:3353-5.

Chao, J, Wistreich, G, A, 1960: Microorganisms from the midgut of larval and adult Culex quinquefasciatus Say. J. Insect Pathol. 2:220-4.

Chao, J, Wistreich, GA, 1995: Microbial isolation from the midgut of Culex tarsalis Coquillett. J. Insect Pathol. 1:311-8.

Choo, QL, Kuo, G, Weiner, A, J, Overby, LR, Bradley, DW, et al, 1989: Isolation of cDNA clone derived from a blood-borne non-A, non-B viral hepatitis genome. J. Sci. 244:395-62.

Ciorlia, LAS, Zanetta, DMT, 2005: Hepatitis B in Healthcare Workers: Prevalence, Vaccination and Relation to Occupational Factors. Braz J. Infect. Dis. 9, 5:384-9.

Coppola, N, De Pascalis, S, Onorato, L, Calò, F, Sagnelli, C, et al, 2016: Hepatitis B virus and hepatitis $\mathrm{C}$ virus infection in healthcare workers. World J. Hepatol. 8, 5:273-81.

Darwish, M, Hoogstraal, H, 1981: Arboviruses infesting human and lower animals in Egypt., A review of thirty years of research. J. Egypt. Pub. Hlth. Assoc. 56:107-12.

Demaio, J, Pumpuni, CB, Kent, M, Beier, JC, 1996: The midgut bacterial flora of wild Aedes triseriatus, Culex pipiens, and Psorophora columbiae mosquitoes. Am. J. Trop. Med. Hyg. 54:219-23.

Deuffic-Burban, S, Delarocque-Astagneau, E, Abiteboul, D, Bouvet, E, Yazdanpanah, Y, 2011: Blood-borne viruses in health care workers: Prevention and management. J. Clin. Virol. 52, 1:4-10.

Egypt Health Issues Survey, 2015: Ministry of Health and Population, El-Zanaty and Associates, Cairo, Egypt; The DHS Program ICF International, Rockville, Maryland, USA.
El-Akel, W, El-Sayed, MH, El Kassas, M, et al, 2017: National treatment programme of hepatitis C in Egypt: Hepatitis C virus model of care. J. Viral Hepat. 24:262-7.

El-Bahnasawy, MM, Megahed, LA, Saleh, H A, Morsy, TA, 2013a: The Rift Valley fever: Could re-emerge in Egypt again? J. Egypt. Soc. Parasitol. 43, 1:41-56.

El-Bahnasawy, MM, Khater, MK, Morsy, T A, 2013b: The mosquito borne west Nile virus infection: Is it threating to Egypt or a neglected endemic disease? J. Egypt. Soc. Parasitol. 43, 1: 87-102.

Eldin, I, Hablas, A, Ramadan, M, et al, 2014: Cancer incidence in five continents (Egypt, Gharbiah): Steliarova-Foucher E, Ferlay J, Forman D., Cancer incidence in five continents. Lyon, France: International Agency for Research on Cancer, 128-9.

El-Kholy, SE, El-Husseiny, IM, Meshrif, WS, Abou elazem, A, Salem, M L, 2017: Does the mosquito Culex pipiens represent a potential vector of hepatitis C virus? Med. Vet. Entomol. doi: 10.1111/mve.12288.

Fouda, MA, Hassan MI, Hammad, KM, Hasaballah, AI, 2013: Effect of midgut bacteria and two protease inhibitors on the reproductive potential and midgut enzymes of Culex pipiens infected with Wuchereria bancrifti. J. Egypt. Soc. Parasitol. 43, 2:537-45.

Gad, AM, Hammad, RE, Farid, HA, 1996: Uptake and development of Wucheria bancrofti in C. pipiens L. and Ae. caspius Pallas. J. Egypt. Soc. Parasitol. 26, 2:305-14.

Germi, R, Crance, JM, Grain, D, Guimet, J, Thelu, MA, 2001: Mosquito cells bind and replicate hepatitis C virus. J. Med. Virol. 64, 1:6-12. Hassan, MI, Mahdy, H, Lotfy, NM, 1998: Biodiversity of the microbial flora associated with two species of sandflies Phlebotomus papatasi and $P$. langeroni (Diptera: Psychodidae). J. Egypt. Ger. Soc. Zool. 26, E:25-36.

Hassan, MI, Mangoud, AM, Etewa, S, Amin, I, Morsy, TA, et al, 2003: Experimental demonstration of Hepatitis C Virus (HCV) in an Egyptian Strain of Culex pipiens complex. J. Egypt Soc. Parasitol. 33, 2:373-89.

Hayashi, J, Furusyo, N, 2010: Review: Epidemiological and clinical study for hepatitis $\mathrm{C}$ virus infection. Semin. Liver Dis. 30, 3:236-45.

Hubalek, Z, 2008: Review: Mosquito-borne viruses in Europe. Parasitol. Res. 103, 1:29-43. 
Humphrey, JM, Cleton, NB, Reusken, CBE M, Glesby, MJ, Koopmans, MPG, et al, 2017: Urban Chikungunya in the Middle East and North Africa: A systematic review. PLoS Negl. Trop. Dis. Jun 26;11(6):e0005707

Indolfi, G, Resti, M, 2009: Review: Perinatal transmission of hepatitis $\mathrm{C}$ virus infection. J. Med. Virol. 81, 5:836-43.

Kamal, SM, 2008: Acute hepatitis C: A systematic review. Am. J. Gastroenterol. 103, 5:128397.

Karaca, C, Cakalogu, Y, Demir, K, Ozdel, S, Kanymackoglu, S, et al, 2006: Risk factors for the transmission of Hepatitis C Virus infection in the Turkish Population. Diges. Dis. Scin. 51, 2:3-8.

Khalil, M, Malawani, A, Hilmi, I, 1930: The transmission of bancroftian filariasis in Egypt. J. Egypt. Med. Assoc. 15:315-32.

Klitting, R, Gould, EA, Paupy, C, de Lamballerie, X, 2018: What Does the Future Hold for Yellow Fever Virus? (I). Genes (Basel). June 8; 9(6).

Luplertlop, N, Surasombatpattana, P, Patramool, D, 2011: Induction of a peptide with activity against a broad spectrum of pathogens in the Aedes aegypti salivary gland, following infection with Dengue Virus. PLoS Pathogens 7, 1:Article ID e1001252,.

Ma, W, Soliman, AS, Anwar, WA, Hablas, A, B El Din, T, 2018: Forecasted impacts of a sofosbuvir-based national hepatitis $\mathrm{C}$ treatment programme on Egypt's hepatocellular cancer epidemic: Simulation of alternatives. BMJ. Glob. Health 3, 2:e000572.

Meagan, JM, Khalil, GM, Hoogstraal, H, Adham, FK, 1980: Experimental transmission and field isolation studies implicating Culex pipiens as a vector of Rift Valley virus in Egypt. Am. J. Trop. Med. Hyg. 80:1405-10.

Pelah, D, Abramovich, Z, Markus, A, Wiesman, Z, 2002: The use of commercial saponin from Quillaje saponaria bark as a natural larvicidal agent against Ae. aegypti and C. pipiens. J. Ethnopharmacol. 81, 3:407-10.

Prüss-Ustün, A, Rapiti, E, Hutin, Y, 2005: Estimation of the global burden of disease attributable to contaminated sharps injuries among the health-care workers. Am. J. Ind. Med. 48, 5:48290.

Pumpuni, CB. Demaio, J, Kent, M, Davis, JR, Beier, JC, 1996: Bacterial population dynamics in three anopheline species: impact on Plasmodium sporogonic development. Am. J. Trop. Med. Hyg. 54:214-8.

Pybus, OG, Peter, VM, Anna, AW, Andrew, J T, 2007: Investigating the endemic transmission of the Hepatitis C Virus. Int. J. Parasit. 37:83949.

Ramirez, JL, Dimopoulos, G, 2008: The Aedes aegypti: Toll pathway controls Dengue virus infection. PLoS Pathogens 4, 7: IDe1000098.

Ramirez, JL, Dimopoulos, G, 2010: The toll immune signaling pathway control conserved anti-dengue defenses across diverse Ae. aegypti strains and againstmultiple dengue virus serotypes. Develop. Comparat. Immunol. 34, 6:625-9.

Schlein, Y, Polacheck, I, Yuval, B, 1985: Mycoses, bacterial infections and antibacterial activity in sandflies (Psychodidae) and their possible role in the transmission of leishmaniasis. J. Parasitol. 90:57-66.

Seitz, HM, Maier, WA, Rottok, M, Becker, F H, 1987: Concomitant infections of Anopheles staphensi with Plasmodium berghei and Serratia marcescens: additive detrimental effects. ZBL. Bakt-Int. J. Med. M. 266:155-66.

Silver, AL, Mecray, DG, Gordon, SC, Morgan, WT, Walker, ED, 1996: Experimental evidence against replication or dissemination of hepatitis $\mathrm{C}$ virus in mosquitoes (Diptera: $\mathrm{Cu}$ licidae) using detection by reverse transcriptase polymerase chain reaction. J. Med. Entomol. 33, 5:398-401.

Strauss, JH, Strauss, EG, 2002: Viruses and Human Disease. ${ }^{\text {st }}$ Edition, Academic Press.

Sy, T, Jamal, MM, 2006: Review: Epidemiology of Hepatitis C Virus (HCV) Infection. Int. J. Med. Sci. 3, 2:41-6;65-9.

Tarantola, A, Abiteboul, D, Rachline, A, 2005: Infection risks following accidental exposure to blood or body fluids in health care workers: A review of pathogens transmitted in published cases. Am. J. Infect. Control 34:367-75.

Tarish, HR, Ghanim, AA, Karar, MA, Rafah, HL, Ghazi, RA, 2014: Role of Culex mosquito in the transmission of hepatitis $\mathrm{C}$ virus: an experimental study in Iraq. Am. J. Res. Commun. 2, 10:176-85.

Tham, HW, Balasubramaniam, V, Ooi, MK, Chew, MF, 2018: Viral determinants and vector competence of Zika Virus transmission. Front Microbiol. 2018 May 23;9:1040. doi: 10.3389/ fmicb.2018.01040. 